\title{
Innovation In The Automotive Industry In Thailand
}

Junyaporn Bunhlua, Ramkhamhaeng University, Thailand

Peng Chan, (Email: pchan@exchange.fullerton.edu), California State University, Fullerton

\begin{abstract}
This paper reviews the nature of innovation, and seeks to assess the current status of Thailand as an innovative economy, to identify what innovation strategies are available and are being implemented, and to examine in some detail the automotive sector as a case in point. Thailand is gaining recognition as the "Detroit of Southeast Asia." Both Japanese and American automobile manufacturers are investing heavily in Thailand, bringing with them the opportunity for local companies to become part of the supply chain. The Thai government has the opportunity to assist these Thai companies to become innovative, with some expectation of innovation-related spin-off effects for other manufacturing sectors. This paper describes some of the Thai government programs in support of innovation, and assesses the government's communication strategy in making Thai companies aware of its programs and getting Thai companies to buy into its programs.
\end{abstract}

\section{INTRODUCTION}

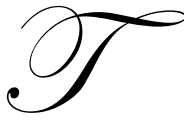

he rapid uptake of innovation as a factor in national competitive strategies has forced leaders to look around and inward in assessing their economy's competitiveness. It is generally agreed that innovation is a key success factor for competitiveness now and in the future. Indeed, countries that have been slow to make innovation a cornerstone of economic development are already at risk of being left out of global economic growth.

Thailand by some accounts is one of the laggards in developing and implementing a national innovation system. Over the last decade the interest in science and technology has been slow to attract government attention and funding. This has changed for the better in the past three or four years under the Thaksin Shinawatra regime, but there are still large steps required to turn Thailand into a competitive nation based on research and development.

\section{THE MEANING OF INNOVATION}

Definitions of innovation vary widely, from the abstraction offered by Webster's dictionary (2002: 502) "An innovation in the making of a change in something established" to a specific, marketing focused interpretation "Product innovation, results in new or improved products and is only partially captured by existing techniques. Process innovation results in reduced production cost and is readily measured by existing techniques of data collection" (Tompson \& Waldo, 2000.) Perhaps definitions more encompassing are better for our purposes:

$>\quad$ "An innovation encompasses the full spectrum, from creative idea generation though full profitable commercialization. Successful innovation depends on converting knowledge stocks and flows into marketable goods \& services." (Amidon, $2003: 9$ )

"An innovation means coming up with new ideas about how to do things better or faster, making a product or offering a service that no one had thought of before, putting new ideas to work in its business or industry and having a skill work force that can use those new ideas.” (Industry Canada, $2002: 1$ )

In all cases, innovation implies and requires creativity and imagination, change and improvement, and both tangible and intangible results. 
Haiyang Li and Kwaku Atuahene-Gima recall that Brown and Eisenhardt (1995) identified two major research approaches to the study of innovation. Firstly, the examination of technology diffusion needs to be considered on a macro level across nations and industries, with an ultimate focus on the company itself. In this context, innovation can be operationally defined "as a technology strategy or management practice that a firm is using for the first time, whether or not other organizations or users have previously adopted it, or as a significant restructuring or improvement in the process (Nord \& Tucker, 1987: 9.)" The second approach looks inside the firm to its product line, to examine "the influence of organizational structures, processes and people on the development and marketing of new products (e.g. Zirger \& Maidique, 1990.) Here, the research focus refers to new products that an organization has created for the market, whether "upgrades, modifications and extensions of existing products" that are new either to the firm or the market.

The influence of organizational structures, processes and people on the development and marketing of new products may be further split into two categories. The first category "focuses on the project level and examines all the activities needed to conceive, design, produce and deliver a new product to the market (Zirger \& Maidique, 1990.) The second category focuses on the firm or strategic business unit (SBU) as a unit for analysis and examines product innovation as a dimension of the entrepreneurial strategic posture of firms (Zahra \& Covin, 1993.) Objective evidence of a firm's product innovation strategic posture may take several forms, such as the level of R\&D expenditures (Boulding \& Staelin, 1995) and the number of engineers, scientists and other technical personnel employed (McCann, 1991.) Subjective evidence may include evaluations of a firm's degree of emphasis - in terms of resource allocation on new product development and varieties of new product lines (Zahra \& Covin, 1993.)"

In terms of timeframes for innovation, it is recognized that the change process may be radical and quick or slow and incremental. Not all organizations need to make radical changes to survive. Most innovation is gradual, moving incrementally forward with a sequence of cumulative improvements. For instance, the dramatic growth and success of the Japanese car manufacturing industry are primarily the result of a 40 year program of systematic and continuous improvement of product and process design (Womack et al, 1991.)

Still, at the company level, there often is a time imperative on a sectoral or industry scale for innovation. The speed with which firms can adapt and adopt or develop new technologies can have a critical effect on their ability to compete. The deployment of new Information Technologies can be a determining factor in a company's inclusion or exclusion from a supply chain; for example, specific information technologies mandated by distribution channel captains can force supply chain members to replace information systems or be dropped as a supplier.

\section{INNOVATION STRATEGIES}

Debra M. Amidon, in The Innovation Superhighway, identifies ten dimensions of innovation strategies (Figure 3.2, p. 179-192). These dimensions have emerged as an excellent way to calibrate an organization's capacity to innovate. The ten steps associated with these dimensions enable a company to assess where it is on the scale of innovation management capability and provide a foundation for strategy formulation:

\section{Focus On Collaborative Process}

Trust and reliability are seen as becoming more important. Many progressive enterprises are realizing that managing the process explicitly is a path toward more sustainable innovation.

\section{Focus On Performance Measures}

The measurement only of financial indicators of an enterprise or a nation has been inadequate. Recently, intangible assets are seen as being more valuable than tangible ones. "Microsoft's only factory asset is the human imagination" - Bill Gates. New performance indicators that have been recorded on company balance sheets as "intangible assets" or "intellectual capital" include the quality of the company's mission statement, capacity for knowledge re-use, staff turnover and customer loyalty. 


\section{Focus On Education And Training}

Organizations need creativity and active learning in order to survive in a hostile competitive environment. "Investments in assets like buildings, equipment or IT systems may help the business, but without a core learning capability, the long-term future must be in doubt (Bessant, 2003, p7.)"

\section{Focus On Distributed Networks}

There has been a dramatic shift from hierarchical management to networked learning systems in which all stakeholders, both inside and outside the enterprise, become sources of knowledge. Everyone carries the basic creative capabilities for finding and solving problems and exploring new opportunities. The question is how people are receptive to the ideas of others. As long as people feel supported and enabled, and they buy into a shared sense of direction, they will generate projects and solutions that keep driving the number on quality, time, cost, etc in the right direction.

\section{Focus On Competitive Intelligence}

In today's economy, it is required to have a sense of the competitor's capacity to innovate - to create ideas, and put them into products and services - in advance of the competition. A strategic plan for innovation based on competitive intelligence avoids effort on research and development and marketing that cannot compete against superior forces.

\section{Focus On New Products And Services}

The world has become more cognizant of environmental factors and is looking forward to ecological systems and economic sustainability as a foundation for new product development. Product life cycles are predicted to be shorter, with waves of new, more complex generations of products spanned by intensive innovation.

\section{Focus On Strategic Alliances}

The art of managing strategic alliances will become ever more critical in the coming decade. Managing such complex relationships requires both foresight and skill to leverage the competencies from which both or all parties might benefit.

\section{Focus On Market/Customer Interaction}

As global competition has intensified and relationships with customers become increasingly more important, enterprises are realizing that communication of important information is critical. Market perception, regardless of accuracy, can make or break the competitive positioning of an organization. Further, the relationship with external sources, especially customers, may be the key to future product and service.

\section{Focus On Leadership/Leverage}

The knowledge economy demands a very different form of leadership. The nature of leadership is seen as assisting expert workers to achieve both their personal and common purposes. One of the common purposes of this kind of knowledge organization is to the benefit of managers and workers.

\section{Focus On Computer/Communications Technology}

Electronic systems have become a learning tool in enterprises. They are vehicles to facilitate innovation conversations across borders that increase the global reach of enterprises and the individual entrepreneur. Progressive managers are seeing the value of using the technology infrastructure for learning organizations. 


\section{NATIONAL INNOVATION SYSTEMS}

There is general recognition among government policy makers, academics and enlightened industry leaders that the constituent parts of a nation must now work together to build an innovative society. The components and players of such a system can be described as in the generic diagram below, featured on the Australian government's website (See below).

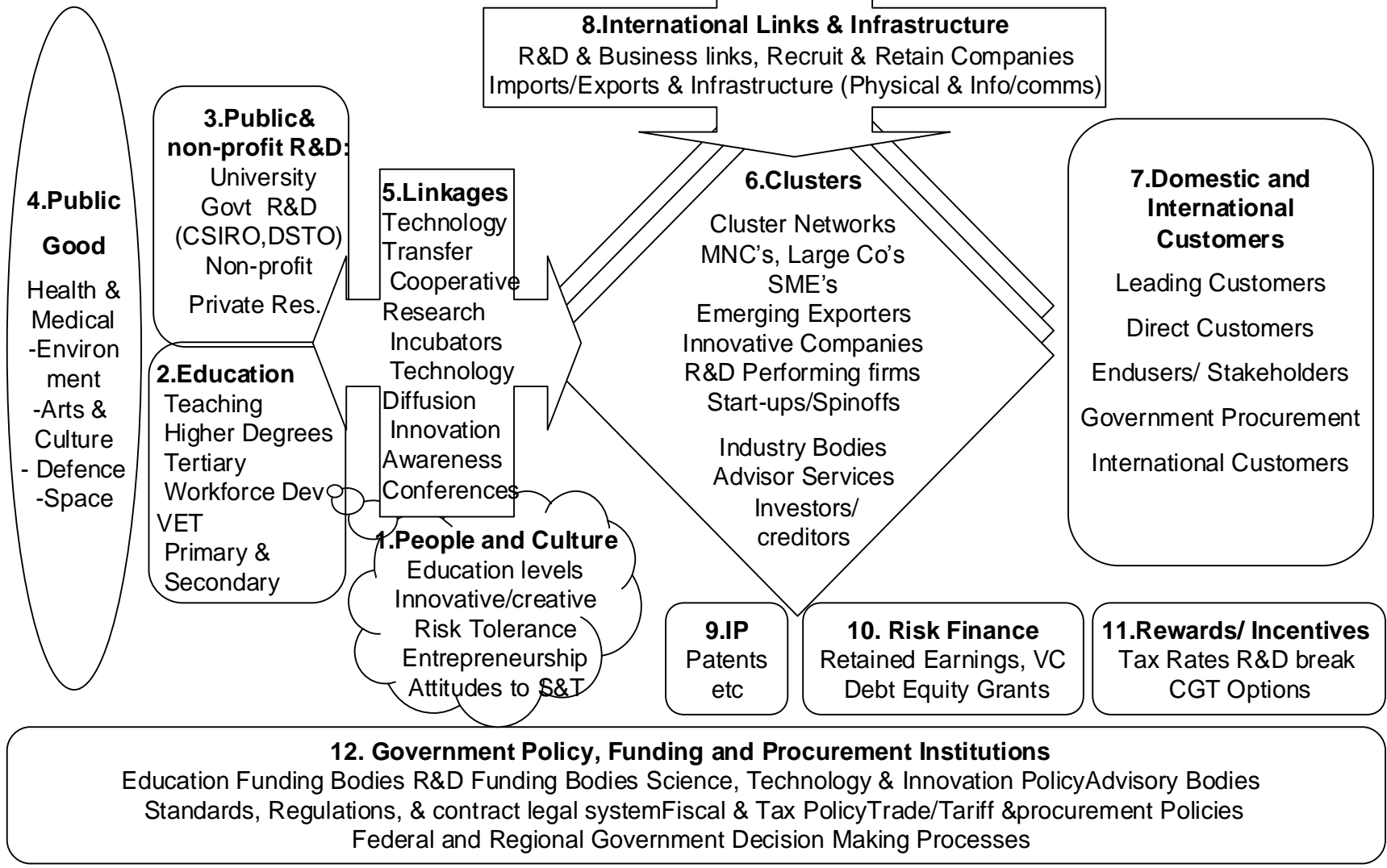

Success in moving the country forward are predicated on the degree to which opinion leaders and decision makers can work together with a single vision, with sufficient well-targeted financial resources, and with education and training for the populace. The coordination of the various constituencies and the communication between them requires the active engagement of the federal government.

\section{INNOVATION IN THAILAND}

Using general measures, there is no real evidence that Thailand is operating at increasingly higher technological levels in the production process. (Lall, P 4). Several studies of Thai firms conducted since the 1990s show that most firms have grown without deepening their technological capabilities for the long run, and their technological learning has been very slow and passive (See Dahlman and Brimble 1990; Tiralap, 1990; Mukdapitax, 1994, Lall, 1998, Sevilla and Soonthornthadu, 2000; Intarakumnerd, 2002). Doner and Ritchie (2003) note that 
"the technology and industrial base of Thailand has remained bifurcated, with most high technology products imported for assembly. Local industry is still highly protected, working at the low-tech end, and is largely oriented toward the domestic economy. Because of the country's week engineering base, indigenous firms have been unable to absorb many technologies from abroad, and the country has been unable to develop a large pool of technological talent."

That Thailand is a laggard in innovation critical to productivity in the private sector has been confirmed by analyses from both the International Institute for Management Development (IMD) and World Economic Forum (WEF.) Thailand's competitiveness ranking by IMD and WEF show that Thailand has a long way to go to reach even the top 20 nations in the world:

Table 1: Thailand's Competitiveness Ranking By IMD And WEF

\begin{tabular}{cccc}
\hline Year & IMD $^{\mathbf{1}}$ & WEF $^{\mathbf{2}}$ \\
\hline 2002 & 34 & 33 & \\
2001 & 38 & 30 & \\
\hline
\end{tabular}

Sources :IMD (2002). The World Competitiveness Yearbook 2002. WEF (2002). The Global Competitiveness Report 2001-2002. 1. from 49 countries. 2. from 58 countries.

WEF's Innovative Capacity Index uses 1. Proportion of scientists and engineers, 2. Innovation policy, 3. Cluster innovation environment and 4. Linkages. In 2002, WEF ranked Thai $46^{\mathrm{th}}$ of 71 countries in innovative capacity. By separation by each index Thailand ranked between $30^{\text {th }}$ and $60^{\text {th }}: 60^{\text {th }}$ in Proportion of S\& E, $30^{\text {th }}$ in Innovation policy, $40^{\text {th }}$ in Cluster innovation environment and $49^{\text {th }}$ in Linkages.

Thailand is similar to the East Asian New Industrial Economics, NIEs, of Korea, Taiwan, Singapore, and Hong Kong, in that its economic structure has changed from an agriculture - based economy to an economy in which the industrial sector has gained distinctive significance. Agriculture's share of GDP has dropped remarkably from almost $40 \%$ in the 1960 s to approximately $10 \%$ in the year 2003 , while the manufacturing rose to about $40 \%$ in the same year. As the table below indicates, the manufacturing sector has grown considerably both in the form of growth of production, and in share of total exports, which was once dominated by agricultural commodities such as rice, rubber, teak and tapioca.

Table 2: Thailand's Shift From Agriculture To Manufacturing - Top 10 Exports As An Indicator

\begin{tabular}{|c|c|c|c|c|c|}
\hline Rank & 1999 & 2000 & 2001 & 2002 & 2003 \\
\hline 1 & $\begin{array}{c}\text { Computers \& Parts } \\
307.3 \text { \$Bn. }\end{array}$ & $\begin{array}{c}\text { Computers \& Parts } \\
348.1 \text { \$Bn. }\end{array}$ & $\begin{array}{l}\text { Computers \& Parts } \\
351.8 \text { \$Bn. }\end{array}$ & $\begin{array}{c}\text { Computers \& Parts } \\
320.6 \text { \$Bn. }\end{array}$ & $\begin{array}{c}\text { Computers \& Parts } \\
340.1 \text { \$Bn. }\end{array}$ \\
\hline 2 & $\begin{array}{c}\text { I.C. } \\
111.8 \$ B n .\end{array}$ & $\begin{array}{c}\text { I.C. } \\
179.3 \$ \mathrm{Bn} .\end{array}$ & $\begin{array}{c}\text { I.C. } \\
154.9 \$ \mathrm{Bn} .\end{array}$ & $\begin{array}{c}\text { I.C. } \\
148.1 \$ B n .\end{array}$ & $\begin{array}{c}\text { I.C. } \\
191.6 \$ \mathrm{Bn} .\end{array}$ \\
\hline 3 & $\begin{array}{l}\text { Garments } \\
110.3 \$ B n .\end{array}$ & $\begin{array}{l}\text { Garments } \\
124.2 \$ B n .\end{array}$ & $\begin{array}{l}\text { Garments } \\
129.1 \text { \$Bn. }\end{array}$ & $\begin{array}{c}\text { Automobiles \& Parts } \\
125.3 \text { \$Bn. }\end{array}$ & $\begin{array}{c}\text { Automobiles \& Parts } \\
165.1 \$ B n .\end{array}$ \\
\hline 4 & $\begin{array}{c}\text { Canned Seafood } \\
76.4 \$ \mathrm{Bn} .\end{array}$ & $\begin{array}{c}\text { Automobiles \& Parts } \\
96.5 \$ \mathrm{Bn} .\end{array}$ & $\begin{array}{c}\text { Automobiles \& Parts } \\
117.6 \$ \mathrm{Bn} .\end{array}$ & $\begin{array}{l}\text { Garments } \\
116.6 \$ \mathrm{Bn} \text {. }\end{array}$ & $\begin{array}{c}\text { Rubber } \\
115.8 \text { \$Bn. }\end{array}$ \\
\hline 5 & $\begin{array}{c}\text { Rice } \\
73.8 \$ \mathrm{Bn} .\end{array}$ & $\begin{array}{c}\text { Canned Seafood } \\
82.8 \text { \$Bn. }\end{array}$ & $\begin{array}{c}\text { Canned Seafood } \\
\text { 89.4 \$Bn. }\end{array}$ & $\begin{array}{c}\text { Gems \& Jewelry } \\
93.1 \text { \$Bn. }\end{array}$ & $\begin{array}{l}\text { Garments } \\
114.9 \$ B n .\end{array}$ \\
\hline 6 & $\begin{array}{c}\text { Automobiles \& Parts } \\
72.0 \$ \mathrm{Bn} .\end{array}$ & $\begin{array}{c}\text { Radios \& TV } \\
78.0 \$ \mathrm{Bn} .\end{array}$ & $\begin{array}{c}\text { Gems \& Jewelry } \\
81.3 \$ \text { Bn. }\end{array}$ & $\begin{array}{c}\text { Radios \& TV } \\
90.1 \$ B n\end{array}$ & $\begin{array}{c}\text { Gems \& Jewelry } \\
104.5 \$ \mathrm{Bn} .\end{array}$ \\
\hline 7 & $\begin{array}{c}\text { Gems \& Jewelry } \\
67.5 \$ \mathrm{Bn} .\end{array}$ & $\begin{array}{c}\text { Plastic Pellets } \\
74.0 \$ \mathrm{Bn} .\end{array}$ & $\begin{array}{c}\text { Radios \& TV } \\
74.9 \$ \mathrm{Bn} .\end{array}$ & $\begin{array}{c}\text { Canned Seafood } \\
86.5 \$ \mathrm{Bn} .\end{array}$ & $\begin{array}{c}\text { Radios \& TV } \\
103.8 \$ \mathrm{Bn} .\end{array}$ \\
\hline 8 & $\begin{array}{c}\text { Radios \& TV } \\
51.2 \$ \mathrm{Bn} .\end{array}$ & $\begin{array}{c}\text { Gems \& Jewelry } \\
69.4 \$ \mathrm{Bn} .\end{array}$ & $\begin{array}{c}\text { Plastic Pellets } \\
71.4 \$ \mathrm{Bn} .\end{array}$ & $\begin{array}{c}\text { Plastic Pellets } \\
77.1 \$ \mathrm{Bn} .\end{array}$ & $\begin{array}{c}\text { Plastic Pellets } \\
89.3 \text { \$Bn. }\end{array}$ \\
\hline 9 & $\begin{array}{c}\text { Frozen Shrimps } \\
48.3 \$ \mathrm{Bn} .\end{array}$ & $\begin{array}{c}\text { Rice } \\
65.6 \$ \mathrm{Bn} .\end{array}$ & $\begin{array}{c}\text { Rice } \\
70.1 \$ \mathrm{Bn} .\end{array}$ & $\begin{array}{l}\text { Rubber } \\
74.6 \$ \mathrm{Bn} .\end{array}$ & $\begin{array}{c}\text { Canned Seafood } \\
\text { 88.9 \$Bn. }\end{array}$ \\
\hline 10 & $\begin{array}{c}\text { Plastic Pellets } \\
46.0 \$ \mathrm{Bn} .\end{array}$ & $\begin{array}{l}\text { Rubber } \\
60.7 \$ B n .\end{array}$ & $\begin{array}{l}\text { Rubber } \\
58.7 \$ \text { Bn. }\end{array}$ & $\begin{array}{c}\text { Rice } \\
70.0 \$ \mathrm{Bn} .\end{array}$ & $\begin{array}{c}\text { Rice } \\
76.7 \$ \mathrm{Bn} .\end{array}$ \\
\hline
\end{tabular}

Source: Department of Trade Negotiations, Ministry of Commerce 
Table 3: Thailand's Export Structure

\begin{tabular}{|c|c|c|c|c|c|c|c|c|c|}
\hline \multirow[b]{2}{*}{ Items } & \multicolumn{3}{|c|}{1999} & \multicolumn{3}{|c|}{2000} & \multicolumn{3}{|c|}{2001} \\
\hline & Value & Growth & Share & Value & Growth & Share & Value & Growth & Share \\
\hline & US\$ Mil. & Rate \% & $\%$ & US\$ Mil. & Rate \% & $\%$ & US\$ Mil. & Rate \% & $\%$ \\
\hline $\begin{array}{l}\text { Agricultural } \\
\text { Products }\end{array}$ & 7,012 & -1.4 & 12.0 & 7,337 & 4.6 & 10.5 & 7,056 & -3.8 & 10.8 \\
\hline $\begin{array}{l}\text { Argo- } \\
\text { Industrial } \\
\text { Products }\end{array}$ & 4,559 & 7.2 & 7.8 & 4,719 & 3.5 & 6.8 & 4,818 & 2.1 & 7.4 \\
\hline $\begin{array}{l}\text { Principal } \\
\text { Manufacturing } \\
\text { Products }\end{array}$ & 43,960 & 9.1 & 75.2 & 53,252 & 21.1 & 76.5 & 49,083 & -7.8 & 75.3 \\
\hline $\begin{array}{l}\text { Mining \& } \\
\text { Fuel Products }\end{array}$ & 1,265 & 19.2 & 2.2 & 2,419 & 91.2 & 3.5 & 2,047 & -15.4 & 3.1 \\
\hline Others & 1,668 & -4.9 & 2.9 & 1,898 & 13.8 & 2.7 & 2,180 & 14.9 & 3.3 \\
\hline Total & 58,463 & 7.3 & 100.0 & 69,624 & 19.1 & 100.0 & 65,183 & -6.4 & 100.0 \\
\hline
\end{tabular}

\begin{tabular}{|l|c|c|c|c|c|c|}
\hline & \multicolumn{3}{|c|}{$\mathbf{2 0 0 2}$} & \multicolumn{3}{c|}{$\mathbf{2 0 0 3}$} \\
\hline Items & Value & Growth & Share & Value & Growth & Share \\
\hline & US\$ Mil. & Rate \% & \% & US\$ Mil. & Rate \% & \% \\
\hline $\begin{array}{l}\text { Agricultural } \\
\text { Products }\end{array}$ & 7,118 & 0.9 & 10.3 & 8,861 & 24.5 & 11.0 \\
\hline $\begin{array}{l}\text { Argo- } \\
\text { Industrial } \\
\text { Products }\end{array}$ & 5,099 & 5.8 & 7.4 & 5,954 & 16.8 & 7.4 \\
\hline $\begin{array}{l}\text { Principal } \\
\text { Manufacturing } \\
\text { Products }\end{array}$ & 52,558 & 7.1 & 76.4 & 61,365 & 16.8 & 76.5 \\
\hline $\begin{array}{l}\text { Mining \& } \\
\text { Fuel Products }\end{array}$ & 2,002 & -2.2 & 2.9 & 2,303 & 15.0 & 2.9 \\
\hline Others & 2,040 & -6.4 & 3.0 & 1,756 & -13.9 & 2.2 \\
\hline Total & 68,818 & 5.6 & 100.0 & 80,238 & 16.6 & 100.0 \\
\hline
\end{tabular}

Source: Department of Trade Negotiations, Ministry of Commerce

Thailand's performance in spending on research and development compared other nations is one of the causes of its sub-optimal performance in being an innovative country: Thailand's private sector spends one eighth the amount of Singapore's private sector (Table 3) and one sixth the amount spent in total by Singapore on R\&D (Table 4.)

Table 4: Proportion Of R\&D Expenditure Between Public And Private Sector In Selected Developed And Industrializing Economies

\begin{tabular}{ccccc}
\hline & $\begin{array}{c}\text { Private R\&D } \\
\text { Expenditure } \\
\text { (million US\$) }\end{array}$ & $\begin{array}{c}\text { Private R\&D } \\
\text { Expenditure (*) } \\
\text { (million US\$) }\end{array}$ & $\begin{array}{c}\text { Percentage of GDP } \\
\text { in R\&D Expenditure } \\
\text { (Public/Private) }\end{array}$ & $\begin{array}{c}\text { Proportion of } \\
\text { Private/Public } \\
\text { R\&D Expenditure }\end{array}$ \\
\hline Japan & 94,730 & 26,520 & $0.70 / 2.47$ & 78 \\
Singapore & 1,019 & 622 & $0.72 / 1.17$ & 62 \\
Malaysia & 196 & 100 & $0.19 / 0.20$ & 66 \\
Thailand & 124 & 145 & $0.14 / 0.12$ & 47 \\
\hline
\end{tabular}

*Including University and public Research and Technology Organizations (RTO's)

Note: Japan (2000), Singapore (2000), Malaysia (1998) and Thailand (1999) 
Table 5: Gross Expenditure In Research \& Development (GERD) And Proportion Of R\&D Expenditure As Percentage Of GDP In Selected Developed, Newly Industrialized And Developing Economies

\begin{tabular}{llcc}
\hline & & GERD (million US\$) & $\begin{array}{c}\text { Proportion of R\&D } \\
\text { Expenditure and GDP }(\%)\end{array}$ \\
\hline Developed Economies & Japan & 121,250 & 3.17 \\
& The USA & 243,548 & 2.69 \\
Newly Industrialized Economies & Republic of Korea & 10,028 & 2.47 \\
& Taiwan & 5,903 & 2.05 \\
Developing Economies & Singapore & 1,641 & 1.89 \\
& Malaysia & 296 & 0.39 \\
& Thailand & 269 & 0.26 \\
\hline
\end{tabular}

Note: the USA (1999), Japan (2000), Korea (1999), Taiwan (1999), Singapore (2000), Malaysia (1998) and Thailand (1999)

Source: The World Competitiveness Yearbook 2001, IMD; National Survey of R\&D in Singapore 2000, Agency for Science, Technology and Research (A*STAR), National Survey of R\&D 1998, MASTIC; National Statistics Office, Japan.

It was not until after the financial crisis in mid-May 1997 and the subsequent trend toward globalization that firms have begun to realize they cannot rely on competitive advantage or natural resources or labor intensiveness, but have to move rapidly into the use of advanced technology.

\section{THAILAND'S NATIONAL INNOVATION SYSTEM}

Since the first National Economic Development Plan was initiated in 1961, Thailand has followed a consistent policy of purchasing foreign technologies, particularly hard industrial technology and iron - based materials. Previous governments lacked the foresight and dedication of purpose to encourage innovative capability in industry. Foreign Direct Investment was viewed as a way to increase employment levels. Most Thai company managers lacked the ability to transfer technology into their own companies from multi-national firms or other sources due to a lack of skills in English. Thus the lack of production technology and capabilities to develop a firm's technology compounded the problem and disadvantage. Further, Thailand's education system was producing few graduate engineers and scientists: during the period 1997-2001, undergraduate students in science and engineering accounted for only $23 \%$ of the student body. Of these, very few proceeded to graduate school.

Thailand's national innovation system (NIS) encompasses a set of policies and implementation strategies that have been evolving over the past decade. The NIS includes funding support, advisory services and international linkage assistance. Funding for Thai university researchers is available through the Thai Research Fund.

The Thai government offers a number of different programs, including both management and technical advice and financial support, which target the stimulating of innovation in Thai companies. These programs include Invigorating Thai Business (ITB), Thailand Quality Award (TQA) and the Innovation Development Fund. ITB offers business advice and financial support, TQA providing benchmarking services and recognition through awards, and IDF supports innovation with funds for development to improve private sector competitiveness.

Funding support and technical advice for SMEs is provided by the Industrial Technology Research Fund (ITAP), a program developed over the past three years and modeled on the National Research Council Canada's Industrial Research Assistance Program. The National Science and Technology Development Agency (NSTDA), of which ITAP is one part, provides policy analysis and planning for the Ministry of Science and Technology. It also manages the research organizations NECTEC, BIOTech, MTEC, responsible for applied research in Information and Electronic technology, biotechnology and advanced manufacturing respectively. NSTDA is nurturing the growth of several technology clusters in Thailand - in North Bangkok, in Chiang Mai and in Nakorn Si Thammarat in the south. NSTDA's attention is focused on several sectors, with food and automotive being central sectors.

There are still basic structural gaps that need to be addressed: Intarakumnerd and Chairatana (2002) argue that in Thailand there is no interaction between the private and the government sector at the policy level. The existing linkage between research agencies and the industrial sector is concentrated mostly in the areas of contract research, and training and seminars rather than providing consultancy service. 
On a similar note, the World Bank report on Thailand Economic Monitor, (2002) concluded that "despite the large number of public institutes that have been established to support science, technology and innovation... suffer from a label of targeting. There is a lack of coordination amongst agencies, and many of the programs are supply driven. The programs on technological development are not well coordinated with those for skills development. Most Thai's firms base their competitiveness on low labor cost."

\section{THAILAND'S AUTOMOTIVE INDUSTRY}

By 2010 Southeast Asia will become the seventh largest automobile market in the world, with total sales of about three million units a year, and Thailand will become the region's biggest player. Recently Thailand became the largest producer of pickup trucks next to the United States. Both Japanese and American automobile manufacturers plan to make further investments in Thailand as part of their goals to become the largest pickup truck manufacturers in Thailand. There are a number of reasons why the automotive sector in Thailand has seen so much FDI: in the first place, the domestic demand for vehicles is very large in Thailand - in 2002 more than 360,000 units were sold, and in 2003 the number rose to 533,176 units, an increase of about 48\%, and this year it is expected that the number will rise to 700,000 units. (The Thai Automotive Industry Association)

Further, Thailand has comparative advantages in the automotive sector, with a strong supply base, available skilled labour at relatively low cost, and a good transportation infrastructure. In 2002 Thailand exported automobiles and parts worth approximately US $\$ 3.2$ billion. Thai government policy has led to support from the Board of Investment to offshore investors, through favorable tax treatment, lower duties and investment support. Combined with this has been evidence of increasing economic and political stability in the country.

However, Michael E. Porter's study has shown that the success of the Thai automotive sector is far from automatic or guaranteed, and requires determined action by government and the private sector. Thailand has enjoyed competitive advantage in costs. Because of low factor input costs; yet, the productivity level is low, and there is a mismatch between available work force skills, the needs of the manufacturers, and the lack of innovative capacity.

A major policy of the Thai government is to improve automotive sector competitiveness through increases in productivity, so that the country can sustain its competitiveness in world markets. One initiative to help realize this goal is the establishment of the Thailand Automotive Institute. The Institute provides training, seminars, information and advice related to the industry, and provides testing services for automotive products and spare parts.

\section{AUTOMOTIVE INDUSTRY SURVEY}

The primary research focuses on the extent to which the government and its programs have been communicating successfully with its target audience. That communication of necessity includes instilling an understanding of the nature and characteristics of the programs, generate participation in the programs, and provide value to the client firms that do participate. These programs have been given the responsibility of injecting an innovative mentality into Thai SMEs. In order to create awareness of their programs, to answer the need for Thai companies to become innovative, and to get SMEs to participate in their programs, they must communicate these issues effectively.

It might be argued that success of a nation's innovation strategy will be at least partially determined by the success with which it communicates with its public. For this reason we have examined government communication of its innovation-oriented programs, in the context of one industry and one group of programs. The automotive industry was chosen for several reasons: it is playing a vital role in the Thai economy already, and appears poised to play an even larger role. The spin-off or spin-out effects of the industry have the potential to be a major catalyst for innovation in other sectors as well. The automotive industry is distinct and distinguishable, well organized as a sector, and accessible through its industry organization. 


\section{RESEARCH DESIGN AND ADMINISTRATION}

A questionnaire was designed to gather information on the company's in the Bangkok automotive sector, to measure their knowledge of government support programs, and to measure the extent to which government programs had added to the technical and managerial capability of the company. It is hypothesized that a high level of government program recognition, demonstrable results of these programs through the hiring of additional engineers and scientists, and perceived increases in managerial skills are good indicators that government programs are contributing to the innovativeness of the sector.

A convenience sample of all the members of the Automotive Institute in the Bangkok area was used. While a Bangkok-resident sample is not necessarily predictive of the country as a whole, it likely does give a good indication of the state of the sector nationally for several reasons. First, concentration of head offices in Bangkok is high; second, most of the government programs supporting innovation are managed from Bangkok, and most of the government program activities are in the Bangkok area.

The Automotive Institute is a proactive promoter of its members, and makes their names and some classification information freely available. It was believed that a mail out of the questionnaire in the metropolitan area would generate a higher response rate within the time available.

Questions were formulated to make the relatively long questionnaire (four pages) as easy to answer as possible. Company information requests were kept to a minimum to avoid concerns of confidentiality. A cover letter was attached to the front of the questionnaire requesting the results be faxed or mailed in the postage-paid envelope. The questionnaire was prepared in both Thai and English; the Thai version was mailed to the target audience.

The empirical date was gathered in October 2003 through mailed questionnaires to all of the Thailand Automotive Institute's members in Bangkok - 111 firms in all. Sixty-five firms in the sample responded to the questionnaire. Three companies had gone out of business, or had moved to another industry. Seven answer sets were incomplete and have not been included in the statistical analysis. Fifty-five automotive firms responded completely, which gave a useable response set rate of 50 percent.

Respondents were invited to telephone the researcher if there were any questions. Several did so, primarily to clarify their questions regarding the programs identified.

\section{DATA ANALYSIS}

Data from 55 automotive firms in Bangkok were collected from the survey: $56.7 \%$ were small companies, with $33.3 \%$ classified as medium-sized companies and $10.0 \%$ as large companies. Small companies were defined as having less than 50 employees, while medium firms were those with between 51 and 250 employees. Large firms have over 250 employees. The industry generally is populated by smaller firms with less than 50 employees; only $10 \%$ of firms have more than 250 employees:

Table 6: Distribution Of Employment Size Of Automotive Industry In Bangkok

\begin{tabular}{|c|c|}
\hline Number of Employees & Percentage of Firms \\
\hline Less than 50 employees & 56.7 \\
\hline $51-250$ employees & 33.3 \\
\hline Over 250 employees & 10.0 \\
\hline Total & 100.0 \\
\hline
\end{tabular}

The industry is capitalized at a low level: almost $97 \%$ of the firms have a capital investment of less than 50 million baht (US\$ $1.25 \mathrm{M})$ : 
There were wide - spread differences in the awareness of different government programs:

$\quad 93.3 \%$ of respondents had heard of the Thailand Automotive Development Program (TADP)

$\quad 86.7 \%$ know of the Invigorating Thai Business (ITB) program

$>\quad 50.0 \%$ know of the Thailand Quality Award (TQA)

$>\quad 36.7 \%$ are aware of the Industrial Technology Assistance Program (ITAP) and

30\% know of the Innovation Development Fund (IDF)

However, most respondents have not been involved with these programs, especially IDF and TQA at 3.3\% each, and TQA at $10 \%$.

Approximately $86.7 \%$ of respondents who have had relationships with the government support programs were increased management capability, especially R\&D planning, business planning and marketing 53.3, 26.7 and 20.0 percent respectively. They have used the newly acquired knowledge to manage their firms (Table 7.)

Table 7: Effect Of Thai Government Support Programs

\begin{tabular}{|c|c|}
\hline Using the New Knowledge & Percentage of Respondents \\
\hline General information and reference & 60.0 \\
\hline Input to the development of new or improved processes & 50.0 \\
\hline Input to the development of new or improved products & 33.3 \\
\hline Input to subsequent research and technical investigation & 26.7 \\
\hline Input to an investment, policy or operation & 16.7 \\
\hline
\end{tabular}

Approximately $66.7 \%$ of respondents acquired technical knowledge through internal R\&D, followed by advice provided by government $50 \%$ and technology transferred from other organizations at $46.7 \%$. However, about 57 percent of respondents did not invest in R\&D in 2002. Twenty-three percent invested less than one million baht, with $13 \%$ investing between one and two million baht, and seven percent investing over two million baht.

Table 8: Investment In R\&D By Size Of Firm (Percentage Of Firms)

\begin{tabular}{|c|c|c|c|c|c|}
\hline & \multicolumn{5}{|c|}{ Amount of Money Invested in R\&D - 2002 } \\
\hline Type of Firm & $\mathbf{0}$ & 1- 1 M Baht & 1-2 M Baht & > 2 M Baht & Percentage Total \\
\hline Small & 50.0 & 6.7 & --- & --- & 56.7 \\
\hline Medium & 7.0 & 16.3 & 10.0 & --- & 33.3 \\
\hline Large & --- & --- & 3.3 & 6.7 & 10.0 \\
\hline Total & 57.0 & 23.0 & 13.3 & 6.7 & 100.0 \\
\hline
\end{tabular}

In terms of using new knowledge and additional financing, the smaller firms proved to be the most benefited from the programs: small firms ranked highest in adding new products to their lines, while medium sized companies implemented new processes more frequently

Table 9: Number Of New Products/Processes And Improved Products/Processes Within 2 To 3 Years (Percentage Of Firms)

\begin{tabular}{|c|c|c|c|c|c|c|c|}
\hline \multicolumn{9}{|c|}{} & \multicolumn{3}{c|}{ Process } \\
\hline Type of firm & New & New & New & Improved & Improved & New & Improved \\
\hline Number & $1-5$ & $6-10$ & $>10$ & $1-5$ & $6-10$ & $1-5$ & $1-5$ \\
\hline Small & 19.8 & 3.3 & --- & --- & --- & 3.3 & 6.7 \\
\hline Medium & 16.7 & 6.7 & --- & 10.0 & --- & 13.3 & 10.0 \\
\hline Large & --- & 6.7 & 3.3 & 6.7 & --- & 3.3 & 3.3 \\
\hline
\end{tabular}




\section{DISCUSSION}

The innovative capability of the Thai automotive industry in Bangkok is not impressive. Investment in R\&D is at a low level, and $57 \%$ of the firms did not invest in R\&D. Most of these firms are small, and are in the OEM business. They do not want to take a high risk in trying to create new products or processes. They sit on the horns of a dilemma: not to innovate may make them non-competitive, but to get into an innovative $R \& D$ program, if the $R \& D$ is not successful, may put them out of business.

The companies that are involved with the Thai government support programs have gained both business knowledge and technical support. Further, they have found the knowledge sufficiently useful to apply it to management issues. Perhaps one of the main benefits that might be gained from this is a Thai management stratum that gains more confidence in itself, which is better able to assess the innovation risks, and in this way find ways to accept higher levels of risk and move forward by being successful.

\section{CONCLUSION}

Organizations worldwide have to cope with very keen competition and a dynamic environment as market conditions change rapidly and as customers demand better and better products \& services. In response to increasing demands, and to maintain competitive advantage, consistently high quality products and services need to be designed, produced, promoted and distributed at a competitive cost to capture and secure market share (AQCL, 1997).

Thailand's private sector must have managerial skills and be innovation oriented to increase productivity. Productivity growth is absolutely fundamental to long-term competitiveness and maintaining profitability. There is general agreement that productivity growth must come from a blend of technology adoption and diffusion, the adoption of more modern and innovative management techniques, better training for staff and workers, and increased risk sharing between government and industry in developing and applying technologies. These latter must come from both offshore and from the coordinated efforts of national innovation systems.

Now is the time for the Thai government to do whatever is required to support R\&D and other forms of innovativeness across a broad spectrum of industries. The new-found growth and optimism in the country, and the returning wealth that the government will enjoy, should be directed to building an innovative culture in Thailand that will allow it to be a strong competitor in Southeast Asia and in the world for the long-term.

\section{REFERENCES}

1. Adler, P. and Kwon, S. (2000). Social capital: Prospects for a new concept. Academy of Management Review, 27: 1, 17-40.

2. $\quad$ Amidon, Debra M., The Innovation Superhighway, Woburn: The Butterwort-Heinemann, 2003.

3. Arnold, E., et al (2000). Enhancing Policy and Institutional Support for Industrial Technology Development in Thailand. World Bank.

4. Bessant, J. High-Involvement Innovation, West Sussex: John Wiley \& Son, 2003.

5. $\quad$ Bessant, J., Tidd, J., and Pavitt, K. Managing Innovation, West Sussex: John Wiley \& Son, 1997.

6. Dodgson, M. and Rothwell, R. The Handbook of Industrial Innovation, Vermont: Edward Elger Publishing, 1996.

7. Doner, R. and Ritchie, B. Economic Crisis and Technological Trajectories. In Crisis and Innovation in Asian Technology, Cambridge: The press Syndicate of The University of Cambridge, 2003.

8. Hadjimanolis, A. and Dickson, K. (2000). Innovation strategy of SMEs in Cyprus, A small Developing Country, International Small Business Journal, Vol. 18, pg 16, 18 pgs.

9. Intaeakamnerd, P., Chairatana, P., and Tangchitpibul, T. National Innovation System in Less Successful Developing Country: The Case of Thailand Research Policy Special Issue, Vol. 31 nos. 8-9, 2002.

10. Jones, O. and Tilley, F. Competitive Advantage in SMEs, West Sussex: John Wiley \& Son, 2003.

11. Lall, S., (1996). Learning from The Asian Tiger: studies in Technology and Industrial Policy, London: Macmillan Press. 
12. Li, H. and Atuahene, Gima K. (2001). Product innovation strategy and the Performance of new technology Ventures in China, Academy of Management Journal, Vol. 44, lss .6 pgs.

13. Mody, Industrial Policy after the East Asian Crisis, Hans J. Peter, Thailand Trade and Infrastructure, paper presented to the conference on Thailand' s Dynamic Economic Recovery and competitiveness, Bangkok, May 20- 21, 1998.

14. Nord, W. R. and Tucker, S. Implementing Routine and Radical Innovations. Lexington, MA: Lexington Books.

15. O' Neill, H. M., Pouder, R. W., and Buchholtz, A. K. (1998) Pattern of Diffusion of Strategies across Organization: Insights from The Innovation Diffusion Literature Review, 23: 14-32.

16. Porter, M. Competitive Advantage of the Nation, New York: The Free Press, 1990.

17. Porter, M. and Ketels, Thailand's Competitiveness: Key Issue in Five Cluster, paper present in Bangkok, May 4, 2003.

18. The World Bank, (2002), Thailand Economic Monitor: Positioning for a Sustainable Recovery, Bangkok, Thailand.

19. Tompson, P. and Woldo, D. (2000) Process versus Product Innovation: Do consumption Data Contain any Information?, Southern Economic Journal. Stillwater: Vol. 67 Iss. Pg 155, 16 pgs.

20. Zirger, B. J. and Maidigue, M. A. (1990). A Model of New Product Development Science, 36: 20-28.

\section{NOTES}

